\title{
SHARING ECONOMY \\ W PRZESTRZENI POLSKICH METROPOLII I MIAST TURYSTYCZNYCH NA PRZYKŁADZIE AIRBNB
}

\begin{abstract}
Abstrakt: Ekonomia współdzielenia (ang. sharing economy) stała się nieodłącznym elementem współczesnej gospodarki turystycznej. Jako alternatywny sposób oferowania dóbr i usług, poza tradycyjnym rynkiem, wywarła istotne zmiany zarówno w sferze funkcjonalnej, jak i przestrzennej turystyki. W artykule podjęto próbę przedstawienia - na przykładzie działalności amerykańskiego serwisu Airbnb - istoty zjawiska sharing economy w turystyce w przestrzeni polskich metropolii i miast turystycznych. Analizie poddano rozmiary tego zjawiska w Polsce, dynamikę jego rozwoju, specyfikę oferty dla turystów, a także kwestie przestrzennego zróżnicowania stopnia jego rozwoju. W badaniach wykorzystano dane źródłowe pozyskane z portalu AirDNA (stan na listopad 2017 r.).
\end{abstract}

Słowa kluczowe: ekonomia współdzielenia, Airbnb, gospodarka turystyczna, studia miejskie, najem krótkoterminowy.

\section{THE SHARING ECONOMY IN THE SPACE OF POLISH CITIES ON THE EXAMPLE OF AIRBNB}

Abstract: The sharing economy has become an inseparable element of the contemporary tourism economy. As an alternative way of offering goods and services, it has significantly changed the global tourism market. The paper attempts to present - on the example of the Airbnb - the phenomenon of sharing economy in tourism in Polish cities. The scale of Airbnb rentals in Poland, the dynamics of its development, the characteristic of the offers, as well as the issues of spatial diversification were analyzed. The study is based on data obtained from the AirDNA portal (as of November 2017).

Keywords: sharing economy, Airbnb, tourism economy, urban studies, short-term rental.

\section{WSTĘP}

Obserwowany w ostatnich latach dynamiczny rozwój ekonomii współdzielenia (sharing economy) oraz tocząca się wokół tych kwestii publiczna i naukowa debata skłania do refleksji nad polskim kontekstem tego zjawiska. Na szczególną uwagę zasługuje sektor turystyczny, w tym zwłaszcza rynek usług noclegowych, który na skutek działalności internetowych platform pośredniczących przechodzi istotne zmiany. Przeobrażenia te kształtują nowy w charakterze i skali społeczno-ekonomiczny wpływ turystyki na miasto oraz jego mieszkańców. Celem artykułu jest przedstawienie - na przykładzie działalności amerykańskiego serwisu Airbnb - istoty zjawiska sharing economy $\mathrm{w}$ przestrzeni polskich metropolii i miast turystycznych oraz próba oceny dynamiki, skali i aktorów rozwoju tej turystycznej innowacji. Do realizacji postawionego celu wykorzystano kwerendę literatury i metodę desk research. Zasadnicze dane źródłowe pozyskano z portalu AirDNA (stan na listopad 2017 r.). 


\section{EKONOMIA WSPÓŁDZIELENIA W TURYSTYCE}

Rozwój nowoczesnych technologii informatyczno-komunikacyjnych (ICT) wpłynął i wciąż wpływa na większość sfer życia społeczno-ekonomicznego. Globalna popularyzacja nowych rozwiązań technologicznych umożliwiła m.in. alternatywny sposób oferowania dóbr i usług (Guttentag, 2015), polegający na wymianie dóbr i usług poza tradycyjnym rynkiem. Idea współdzielenia znajduje zastosowanie w wielu sferach życia codziennego. W sposób szczególnie widoczny rewolucja internetowa przeobraża gospodarkę gościnności (Buhalis, 2003).

Zakres przedmiotowy zjawiska sharing economy pozostaje niejednoznaczny (Dredge, Gyimóthy, 2015; Sinclar, 2016). W literaturze przedmiotu można spotkać wielość jego ujęć (Botsman, 2013; Dredge, Gyimóthy, 2015; Habibi, Kim, Laroche, 2016; Hamari, Sjöklint, Ukkonen, 2016; Pawlusiński, 2017; Skalska, Markiewicz, Pędzierski, 2016), co sprzyja "rozmyciu” tego konstruktu teoretycznego (Czernek, Wójcik, 2017). Dla przykładu, Czernek i Wójcik (2017, s. 68) ujmują go jako „model społeczno-gospodarczy oparty na oddolnych inicjatywach osób (relacje peer to peer - P2P), które odnoszą się do nie w pełni wykorzystanych zasobów, bazując na współdzieleniu realizowanym poprzez platformy technologiczne, za opłatą lub bezpłatnie", jednocześnie nazywając mianem gospodarki współdzielenia. Inni autorzy postrzegają sharing economy nie przez pryzmat specyfiki oferty, ale określonych zachowań konsumpcyjnych, nazywając go mianem konsumpcji kolaboratywnej czy konsumpcji współdzielonej (m.in. Skalska, Markiewicz, Pędzierski, 2016). W polskiej literaturze przedmiotu równie często używa się terminu „ekonomia współdzielenia”, który zakresem przedmiotowym jest zbliżony do gospodarki współdzielenia. Określenie to pojawiło się $\mathrm{w}$ polskiej literaturze przedmiotu jako pierwsze i jest już rozpoznawalne (por. Pawlusiński, 2017; Wyrwińska, Wyrwiński, 2018).

Turystyka jest jednym z tych sektorów, w którym rozwój ekonomii współdzielenia jest najszybszy (Pizam, 2014). Uwidocznia sie to poprzez pryzmat platform technologicznych związanych z zakwaterowaniem oraz transportem (Airbnb, CouchSurfing i BlaBlaCar). Wpływ sharing economy na turystykę staje się coraz bardziej zauważalny zarówno w aspekcie pozytywnym, jak i negatywnym. Obserwowane przeobrażenia dotyczą zmian w strukturze rynku turystycznego, natury produktów i doświadczania turystycznego, rywalizacji między tradycyjnymi a nowymi turystycznymi graczami oraz procesu wytwarzania (społecznej) wartości w turystyce (Sigala, 2017). Ekonomia współdzielenia jest coraz silniej związana z turystyką „poza utartym szlakiem" (ang. tourism off the beaten track - m.in. Stors, Kagermeier, 2015) czy turystyką „w poszukiwaniu codzienności" (ang. living like a local - np. Paulauskaite, Powell, Coca-Stefaniak, Morrison, 2017).

Współcześnie koncepcja ekonomii współdzielenia znajduje zastosowanie $\mathrm{w}$ większości sektorów rynku turystycznego. Najpopularniejsze rozwiązania opierające się na idei współdzielenia, odnoszące się do turystyki, (Majchrzak, 2016; Pawlusiński, 2017; Sigala, 2017) to:

- short-term rental - krótkoterminowy wynajem domów, mieszkań, pokoi przez ich gospodarzy zainteresowanym osobom za pośrednictwem platform internetowych, m.in.: CouchSurfing, Airbnb, HomeAway, HouseTrip czy Onefinestay;

- home swapping - krótkookresowa wymiana domów między ich gospodarzami, np.: HomeExchange, Love Home Swap;

- ride-sharing - np.: Uber, BlaBlaCar, GoCar Share;

- meal-sharing - np.: Eatwith.com, Localseat.com;

- local-guiding - np.: SpottedbyLocals, Trip4real, Vayable;

- equipment sharing - np. Rentoit;

- parking sharing - np. ParkingPanda.

Idea współdzielenia szczególnie szybko rozwija się w miastach, gdzie wolumen wolnych zasobów możliwych do oddania w użytkowanie jest największy, a mieszkańcy cechują się najniższym wskaźnikiem wykluczenia cyfrowego. Umożliwia im to podjęcie nowej aktywności - stają się mikroprzedsiębiorcami, oferując swój majątek rzeczowy i usługi różnym grupom nabywców. W efekcie zrodziło to dwubiegunowy model rynkowy $w$ turystyce $w$ miastach, $\mathrm{z}$ silną konkurencją ze strony mieszkańców w stosunku do tradycyjnych przedsiębiorstw funkcjonujących $\mathrm{w}$ różnych sektorach turystyki, w tym szczególnie sektora noclegowego (Pawlusiński, 2017).

\section{AIRBNB \\ - POCZĄTKI I ROZWÓJ DZIAŁALNOŚCI}

Praktycznym przykładem rozwoju ekonomii współdzielenia na polskim rynku turystycznym jest portal rezerwacyjny Airbnb. Nie jest to pierwszy mechanizm pośrednictwa w sieci pomiędzy usługodawcami noclegowymi i szeroko rozumianymi turystami (wcześniej był m.in. booking.com), ale jako pierwszy wyspecjalizował się w obsłudze nowego zasobu noclegowego, pozostającego dotychczas poza tradycyjnym rynkiem, tj. prywatnych mieszkań i domów. Jak zauważa Pawlusiński (2017) Airbnb zrodziło się jako próba wykorzystania luki podażowej na rynku usług noclegowych, typowej w pewnych okresach w ciągu roku dla dużych miast, w których lawinowo rósł popyt na noclegi do poziomu przekraczającego maksymalną zdolność recepcyjną miasta. Wśród cech modelu 
biznesowego Airbnb na uwagę zasługuje przesunięcie większości opłaty prowizyjnej z gospodarza na gościa (wynajmującego) oraz umożliwienie członkom systemu odgrywania dwóch ról jednocześnie - najemcy i wynajmującego (system wręcz zachęcał, aby w trakcie odbywanej podróży udostępniać swoje mieszkanie innym podróżnym). W krótkim czasie portal Airbnb stał się nie tylko miejscem zawierania transakcji handlowych, ale także zbudował wśród użytkowników poczucie przynależności do globalnej społeczności osób podróżujących, którzy mogą poznać odwiedzane miejsce w sposób szczególny (niedostępny dla turysty korzystającego z tradycyjnej bazy noclegowej), tzn. żyjąc tak, jak ludność miejscowa.

Początki działalności portalu datowane są na 2007 r. W ciągu kolejnych 10 lat z lokalnego przedsięwzięcia w San Francisco Airbnb przerodziło się w globalne przedsięwzięcie. Według oficjalnych danych Airbnb, w końcu 2017 r. na portalu było zarejestrowanych ponad 3 mln ofert z ponad 65 tys. miejsc w 191 krajach. Jak eksponuje portal, jego działalność daje szansę dodatkowego dochodu mieszkańcom, a znacząca część ofert jest zlokalizowana poza obszarami koncentracji tradycyjnego zakwaterowania. Airbnb wskazuje, że uczestnicy systemu cechują się szczególnymi preferencjami nabywczymi:

- $86 \%$ w czasie pobytu w odwiedzanym miejscu chce uczestniczyć w życiu lokalnej społeczności;

- 74\% wybiera na miejsce noclegu lokalizację poza dzielnicami turystycznymi, gdzie znajdują się skupiska hoteli;

- 80\% podkreśla, że ważna jest dla nich autentyczność miejsca, gdzie nocują i przebywają.

W skali Europy największa podaż ofert noclegowych na platformie Airbnb w miastach występuje w stolicach (Paryżu, Londynie, Rzymie, Berlinie) oraz w znanych destynacjach turystycznych (Wenecja, Split), gdzie wskaźnik liczby ofert przypadających na 1 tys. mieszkańców osiąga zwykle najwyższe wartości (Adamiak, 2018).

Globalny sukces platformy Airbnb wywołał dyskusję na temat wpływu współdzielenia na sektor turystyczny, zwłaszcza w ośrodkach miejskich, jak i wpływu na miasto oraz jego mieszkańców. Przykładowo, Sigala (2014) mówi o redefiniowaniu dotychczasowych modeli biznesowych, inni skupiają się na krytyce, zarzucając nieuczciwość nowej konkurencji (Czernek, Wójcik, 2017; Lyons, Wearing, 2015). Coraz częściej portal Airbnb pokazywany jest jako źródło presji turystycznej na obszary mieszkaniowe (Gutierrez, García-Palomares, Romanillos, Salas-Olmedo, 2017), przyczynek do debaty publicznej i medialnej nad konsekwencjami turystyki miejskiej (Kowalczyk-Anioł, Zmyślony, 2017), czy wręcz „maszyna gentryfikacji”, źródło „,kolejnej fali gentryfikacji” (Freytag, Bauder, 2018; Kowalczyk-Anioł, 2018; Mermet, 2017; Stors, Kagermeier, 2017; Wachsmuth, Weisler, 2018).
Powstały też inicjatywy, które monitorują działalność Airbnb - zwłaszcza w relacjach z konsekwencjami, jakie odczuwają mieszkańcy, i mieszkalnictwo w miastach nasiąkniętych ofertą Airbnb. Najbardziej znaną jest Inside Airbnb, która gromadzi dane dotyczące kilkudziesięciu miast z całego świata. Dotychczas jednak Inside Airbnb nie generuje danych na temat miast polskich. Innym dostępnym źródłem jest serwis analityczny AirDNA (Airdna.co), który obejmuje też polskie lokalizacje. Zawiera on dane na temat charakterystyki podaży, popytu i cen usług hotelarskich oferowanych przez Airbnb (udostępniane odpłatnie i nieodpłatnie).

\section{OFERTA AIRBNB W POLSCE ZE SZCZEGÓLNYM UWZGLĘDNIENIEM MIAST}

Platforma Airbnb zainicjowała swoją działalność w Polsce przed Mistrzostwami Piłki Nożnej Euro 2012. Liczba obiektów zarejestrowana na platformie nie przekraczała wówczas 2 tys. W kolejnych latach obserwowano stopniowy wzrost zainteresowania wynajmem pokoi i mieszkań za pośrednictwem Airbnb. Dla przykładu, w Krakowie w 2014 r. na platformie zarejestrowanych było niewiele ponad 800 obiektów, w 2015 - 1,8 tys., a w 2016 r. już 3,8 tys. Podobną dynamikę przyrostu liczby lokali przeznaczonych do wynajmu krótkookresowego zaobserwowano także w Warszawie oraz Trójmieście.

W listopadzie 2017 r. w Polsce w ramach platformy Airbnb funkcjonowało ponad 21 tys. obiektów. Zakładając, że jeden obiekt może pomieścić średnio trzy osoby daje to łącznie ok. 60 tys. miejsc noclegowych. Dla porównania, obiekty rejestrowane w bazie GUS dysponowały 532 tys. całorocznych miejsc noclegowych. Tak więc relacja między szeroko definiowaną bazą hotelarską a bazą Airbnb wynosiła w 2017 r. w Polsce mniej niż 9 do 1. Uwzględniając wysokie tempo przyrostu tego typu obiektów można wnioskować, że w kolejnych latach relacja ta będzie zmieniać się na korzyść Airbnb.

W rozkładzie przestrzennym bazy Airbnb wyraźnie zaznaczają się duże miasta. Sześć największych ludnościowo miast Polski: Warszawa, Kraków, Łódź, Wrocław, Poznań, Gdańsk, skupia ok. 70\% ogółu obiektów zarejestrowanych w ramach Airbnb. Na czele znajduje się Kraków - 5300 obiektów, a kolejno: Warszawa - 4438, Gdańsk - 2393, Wrocław - 1614. Z dużych miast ponad 200 obiektami dysponują także: Poznań (681), Szczecin (285), Łódź (270) i Katowice (227). Oprócz dużych ośrodków miejskich znaczącym udziałem wyróżniały się miasta typowo turystyczne, takie jak: Sopot (846 obiektów), Zakopane (776), Gdynia (693), Świnoujście (438), Kołobrzeg (340). Tabela 1 ujmuje te miasta zestawiając szacowaną liczbę miejsc 
noclegowych w obiektach Airbnb z liczbą całorocznych miejsc noclegowych w obiektach rejestrowanych w bazie GUS. W dużych miastach z największą liczbą obiektów Airbnb - Krakowie, Warszawie, Gdańsku i Wrocławiu - relacja bazy hotelarskiej do bazy Airbnb wynosiła w 2017 r. nawet 2 do 1. W Gdyni, jako jedynym z analizowanych miast, przeważała baza Airbnb. Odwrotnie kształtowała się natomiast relacja w Kołobrzegu (wyposażonym w nowoczesne zakwaterowanie zbiorowe) - tu wynosiła poniżej średniej wartości dla Polski osiągając stosunek prawie 14 do 1.

Tabela 1. Miasta o największej liczbie obiektów Airbnb w Polsce w 2017 r.

\begin{tabular}{|l|c|c|}
\hline \multicolumn{1}{|c|}{ Miasto } & $\begin{array}{c}\text { Szacowana liczba } \\
\text { miejsc noclegowych } \\
\text { w obiektach Airbnb } \\
\text { (w tys.) }\end{array}$ & $\begin{array}{c}\text { Liczba } \\
\text { miejsc noclegowych } \\
\text { całorocznych } \\
\text { w bazie rejestrowanej } \\
\text { GUS (w tys.) }\end{array}$ \\
\hline Kraków & 15,90 & 27,8 \\
\hline Warszawa & 13,30 & 30,7 \\
\hline Gdańsk & 7,20 & 12,3 \\
\hline Wrocław & 4,80 & 10,9 \\
\hline Sopot & 2,50 & 3,6 \\
\hline Zakopane & 2,30 & 12,1 \\
\hline Gdynia & 2,10 & 1,8 \\
\hline Poznań & 2,00 & 9,4 \\
\hline Świnoujście & 1,30 & 8,6 \\
\hline Kołobrzeg & 1,00 & 13,8 \\
\hline Szczecin & 0,86 & 4,8 \\
\hline Łódź & 0,81 & 7,1 \\
\hline Katowice & 0,68 & 4,1 \\
\hline
\end{tabular}

Źródło: GUS oraz szacunki autorów na podstawie AirDNA (listopad 2017).

Analizując wielkość bazy w ramach Airbnb w odniesieniu do głównych regionów turystycznych Polski należy wskazać wyraźną dominację pasa nadmorskiego (łącznie - 6,3 tys. obiektów; 152 obiekty/100 km²). Na obszarach górskich działało 2,3 tys. obiektów, w tym w Karpatach $-1,6$ tys. $\left(8 / 100 \mathrm{~km}^{2}\right)$, a w Sudetach $-0,7$ tys. $\left(7,3 / 100 \mathrm{~km}^{2}\right)$. Znacznie mniejsze znaczenie mają obszary pojezierne. Na całym Pojezierzu Mazurskim współpracowało z Airbnb mniej niż 800 obiektów, co daje średnio 1,6 obiekt na $100 \mathrm{~km}^{2}$.

Ogółem w Polsce w ramach platformy Airbnb udostępnia lokale ok. 9 tys. osób (gospodarzy), z czego tylko w Krakowie, Warszawie i Gdańsku ich liczba wynosi blisko 5 tys. osób. Analiza danych za 2017 r. pokazuje zjawisko postępującej komercjalizacji ekonomii współdzielenia. O ile w okresie początkowym zakładano, że portal Airbnb będzie wspierał głównie właścicieli pojedynczych lokali mieszkalnych, o tyle obecnie widać, że znacząco wzrósł udział gestorów (gospodarzy) dysponujących większą liczbą obiektów. Na rys. 1. przedstawiono wielkość oferty Airbnb w wybranych miastach Polski z uwzględnieniem liczby gospodarzy. Trzy przodujące pod względem stanu rozwoju bazy Airbnb miasta Polski: Kraków, Warszawa, Gdańsk, oferują 12 tys. obiektów, które - jak już wskazano - pozostają w gestii blisko 5 tys. osób, z których ok. 1,5 tys. posiada w dyspozycji więcej niż jeden lokal. Dla przykładu, w Krakowie 640 tzw. multigospodarzy kontroluje aż 4145 lokali.

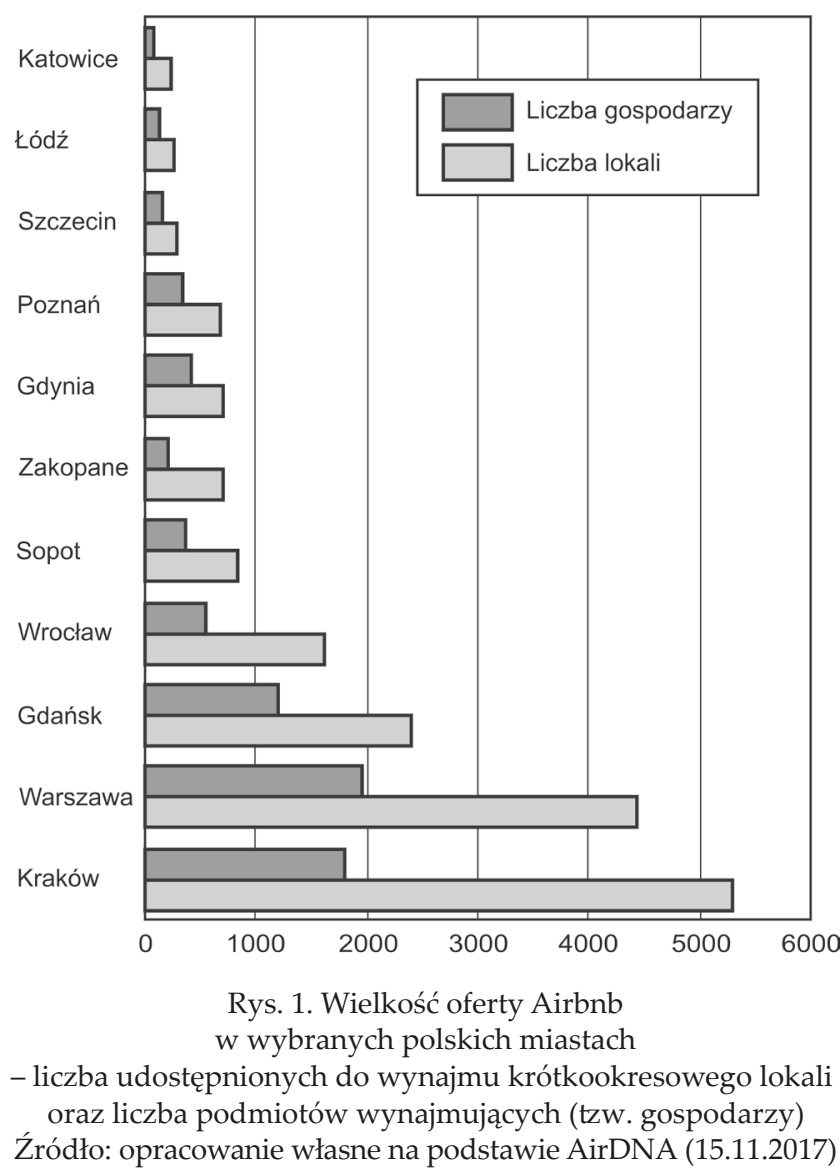

Wysoki wskaźnik koncentracji oferty w ramach Airbnb staje się typowy dla większości ośrodków miejskich kraju: w Zakopanym 38\% ogółu zarejestrowanych gospodarzy dysponuje $81 \%$ wszystkich obiektów, w Katowicach odpowiednio - $42 \%(80 \%)$, Krakowie $-36 \%(78 \%)$, we Wrocławiu - 33\% (77\%), w Sopocie $-31 \%(70 \%)$, a w Warszawie - 27\% (67\%). Jako przyczyny tego zjawiska możemy zidentyfikować dwa procesy. Pierwszy polega na przejmowaniu prawa własności do lokali poprzez umowę kupna-sprzedaży nieruchomości, a następnie ich udostępniania $\mathrm{w}$ ramach najmu krótkoterminowego. $\mathrm{W}$ tym przypadku zakup mieszkania traktuje się jako lokatę kapitału ze stosunkowo wysokim poziomem zwrotu z inwestycji. Drugi opiera się na działalności w imieniu i na zlecenie właściciela lokalu w zakresie jego udostępniania turystom. W tym przypadku gospodarzem obiektu 
nie jest jego prawny właściciel, a jedynie osoba, która otrzymała lokal w użytkowanie, w zamian za określone świadczenia pieniężne należne właścicielowi. Oba wspomniane procesy bardzo istotnie mogą przebudowywać strukturę społeczną nie tylko pojedynczych budynków mieszkalnych, ale także całych kwartałów czy nawet dzielnic.

Przedmiotem oferty noclegowej w ramach Airbnb są przede wszystkim mieszkania i domy prywatne (ok. 75-80\% ogółu obiektów) - rys. 2. Stosunkowo niewiele ofert dotyczy wynajmu krótkookresowego pokoi, zwłaszcza tzw. pokoi współdzielonych (ok. 1\%). Lokale oferowane przez portal Airbnb charakteryzuje różna dostępność w skali roku. W środowiskach wielkomiejskich szczególną uwagę skupia się na zagrożeniu dostępności najmu długookresowego przez rosnącą podaż turystycznego najmu krótkoterminowego. Ich prostą miarą jest udział lokali całorocznych w ofercie Airbnb ${ }^{1}$. Wśród uwzględnionych w badaniu miast najwięcej całych mieszkań oferują Kraków (86\%) oraz miasta nadmorskie - Sopot (86\%), Gdańsk i Szczecin (po 83\%) oraz Gdynia (80\%). Najmniejsza tego typu oferta występuje w Katowicach (66\%) i Łodzi (59\%). Pod względem dostępności najwięcej oferty całorocznej ma Zakopane (67\%), a z pozostałych miast tylko Poznań i Kraków przekroczyły 40\% (odpowiednio 44\% i 42\%). Strukturę oferty Airbnb w polskich miastach charakteryzuje zatem zarówno wspomniana znacząca jej koncentracja w gestii multigospodarzy, jak i dominacja propozycji najmu krótkoterminowego dla całych mieszkań, widoczna zwłaszcza w środowiskach wielkomiejskich atrakcyjnych turystycznie. Rysunek 3 ilustruje je na przykładzie czterech dużych miast z największą ofertą Airbnb zestawionych z Sopotem i Zakopanem - miejscowościami o dominującej funkcji turystycznej.

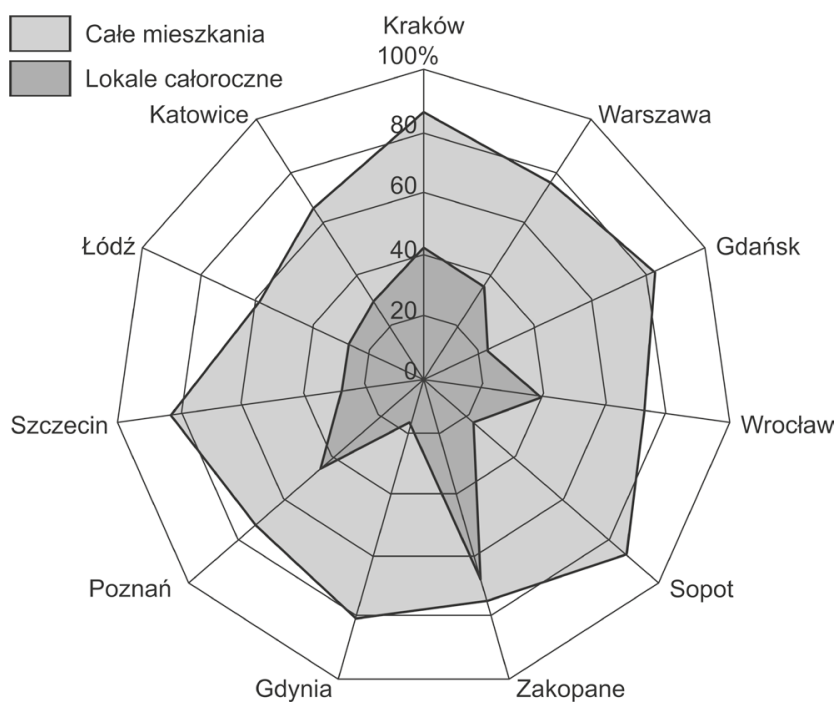

Rys. 2. Oferta Airbnb w wybranych polskich miastach - udział lokali udostępnianych całorocznie i oferty całych mieszkań

Źródło: opracowanie własne na podstawie AirDNA (15.11.2017)
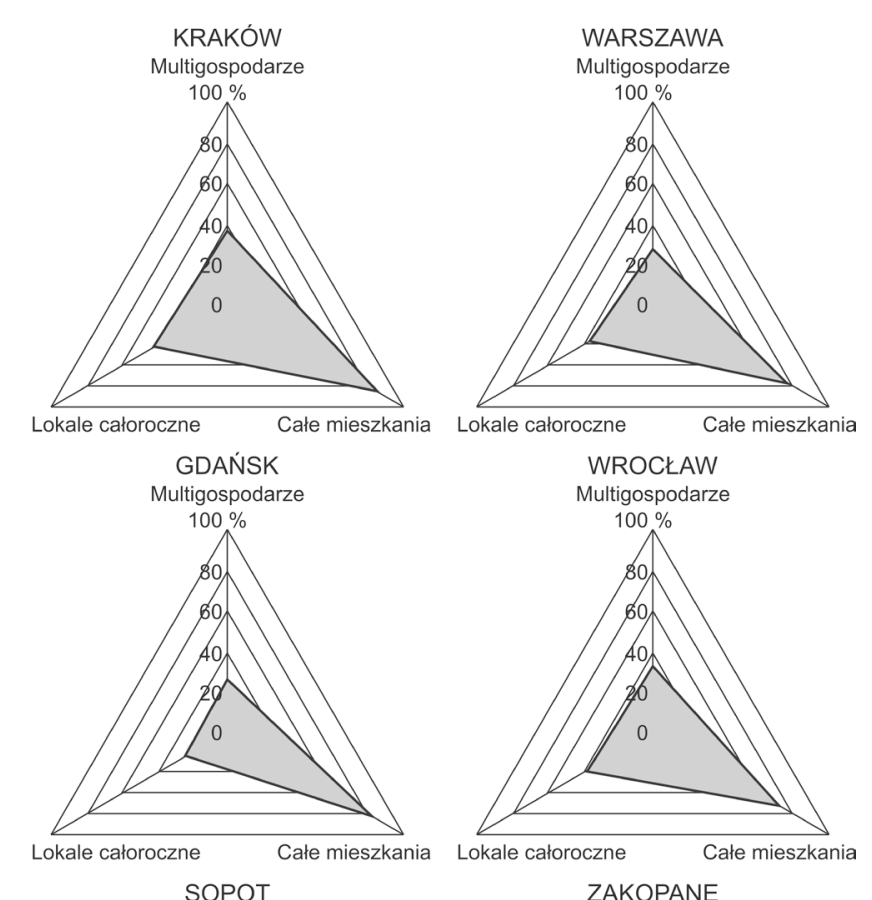

SOPOT

Multigospodarze
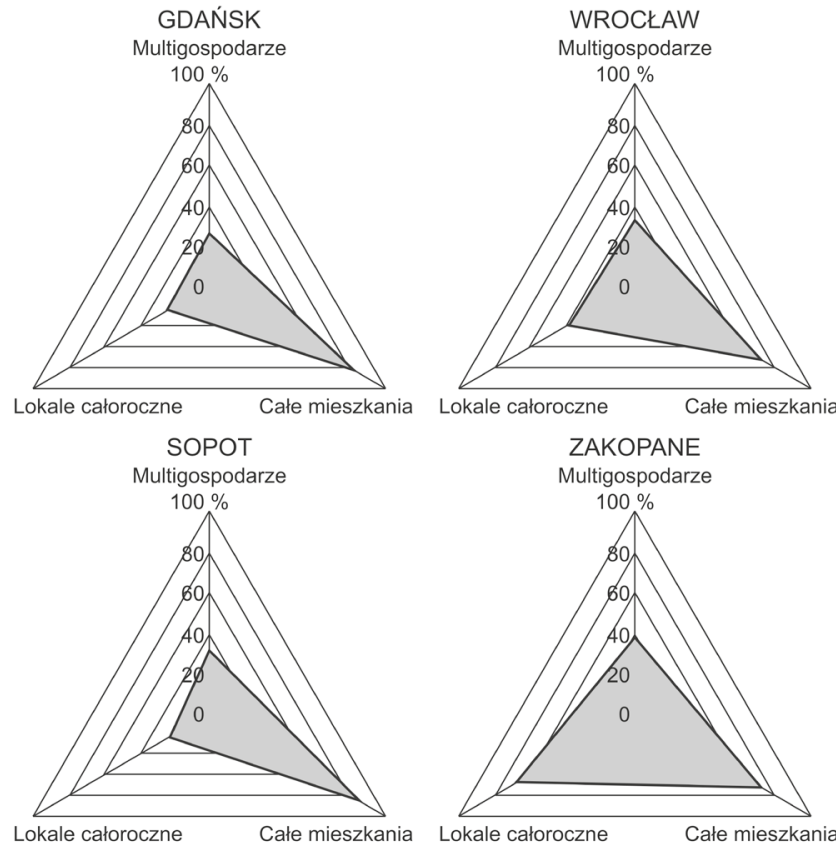

Rys. 3. Struktura oferty Airbnb w wybranych polskich miastach

- udział oferty multigospodarzy, lokali całorocznych i całych mieszkań

Źródło: opracowanie własne na podstawie AirDNA (15.11.2017)

Baza Airbnb zlokalizowana w miastach cieszy się dużą popularnością wśród gości w ciągu całego roku. Z informacji udostępnianych przez portal wynika, że średni wskaźnik obłożenia miejsc w przypadku dużych miast kształtuje się na poziomie między 55\% a 60\%. Dla przykładu, w Warszawie i we Wrocławiu sięga on 70\%, w Krakowie, Łodzi - ok. 60\%, natomiast w Gdańsku, Poznaniu czy Szczecinie przekracza 55\%. Wysokie wartości wskaźnika obłożenia miejsc w przypadku największych aglomeracji Polski świadczą o znacznym udziale w strukturze gości osób przyjeżdżających w celach biznesowych. Niższe wartości tego wskaźnika notuje się w miejscowościach wypoczynkowych - rzędu 30-35\% - co potwierdza ich silne zależności z sezonowością ruchu turystycznego. Wyjątkiem wśród analizowanych miast jest Zakopane, które cechuje duży wzrost obłożenia miejsc zarówno w sezonie letnim, jak i zimowym.

Analiza lokalizacji w przestrzeni polskich miast obiektów z bazy Airbnb pokazuje, że większość oferty koncentruje się wokół głównych atrakcji turystycznych: 


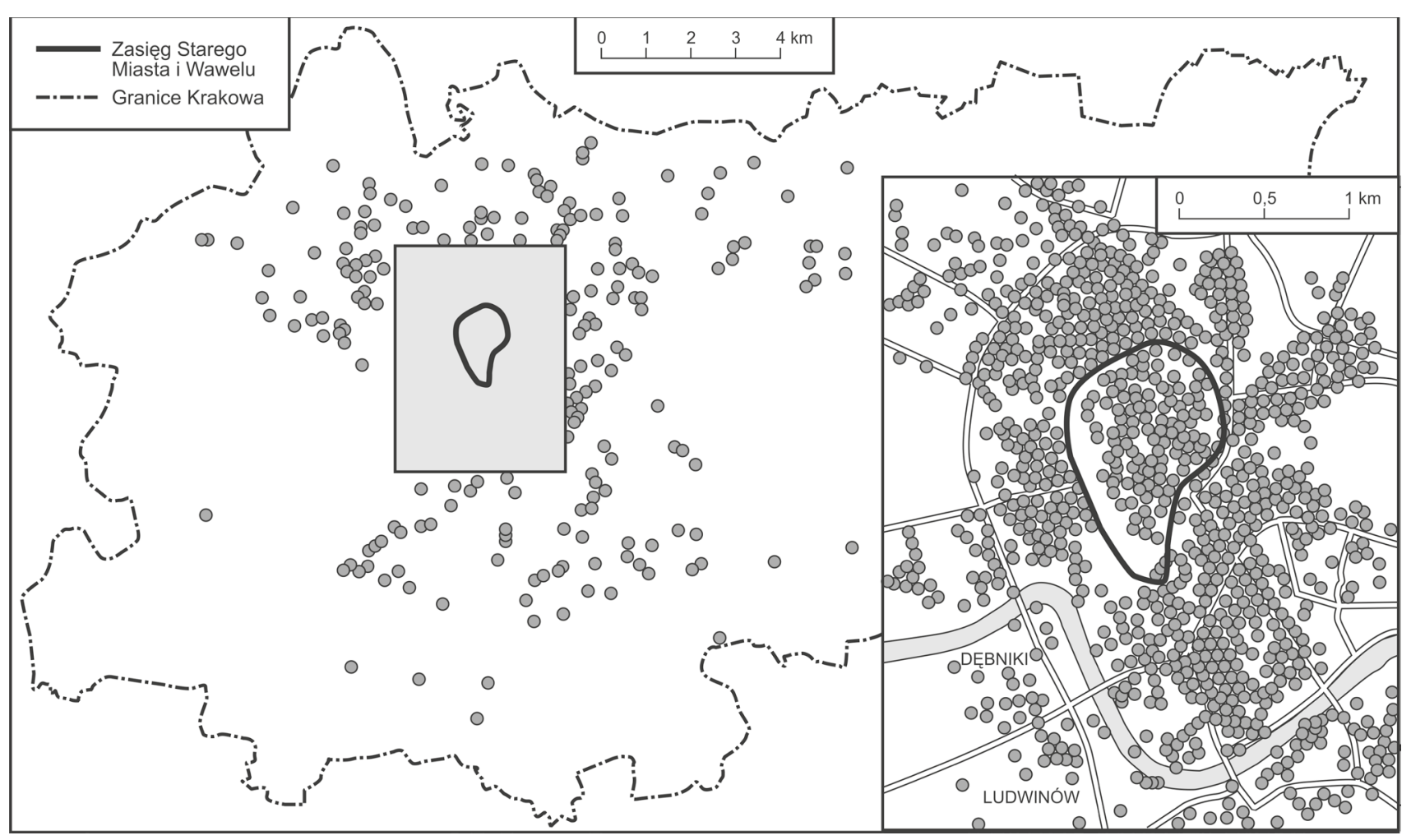

Rys. 4. Obiekty zarejestrowane na platformie Airbnb w przestrzeni Krakowa i historycznego centrum miasta (zaznaczono zasięg Starego Miasta i Wawelu)

Źródło: opracowanie własne na podstawie AirDNA (15.11.2017)

- $\mathrm{w}$ przypadku miast historycznych $\mathrm{w}$ obrębie historycznego rdzenia (przykład Krakowa - rys. 4, w którym większość lokali skupia się w I dzielnicy, w bezpośrednim sąsiedztwie Starego Miasta i Wawelu);

- w przypadku ośrodków położonych w sąsiedztwie ważnego waloru przyrodniczego $\mathrm{w}$ najbliższym jego sąsiedztwie (przykład Sopotu - rys. 5, w którym obiekty oferty koncentrują się wokół najbardziej atrakcyjnego pasa nadmorskiego).

Przykład Gdańska potwierdza te wnioski. Rysunek 6 pokazuje wyraźne dwa skupienia obiektów Airbnb na obszarze miasta - pierwsze wokół historycznej starówki - zwłaszcza atrakcji Głównego Miasta, drugie wokół gdańskiego Jelitkowa (kąpieliska morskiego).

Wyniki te korespondują z wnioskami Sans i Domínguez (2016), według których tradycyjne atrakcje turystyczne są nadal kluczowymi czynnikami promującymi rynek Airbnb. Jednocześnie, wbrew deklaracjom platformy, $\mathrm{w}$ większości polskich miast widać koncentrację oferty w przestrzeni nasyconej tradycyjną bazą noclegowa, co potwierdzili również w kontekście hiszpańskim Gutiérrez, García-Palomares, Romanillos i Salas-Olmedo (2017), zaś na przykładzie Warszawy Gyódi (2018). Zauważył on jednak, że Airbnb przyczynia się do bardziej równomiernego rozpowszechnienia turystyki w Warszawie. Osobliwym przykładem jest $\mathrm{w}$ tym kontekście Łódź, gdzie być może z racji braku jednoznacznie rozpoznawalnego przez turystów centrum miasta i rozproszenie atrakcji turystycznych w mieście rozmieszczenie przestrzenne oferty Airbnb również nie wykazuje skupień, zaś struktura gospodarzy pokazuje znaczący udział indywidualnych gospodarzy.

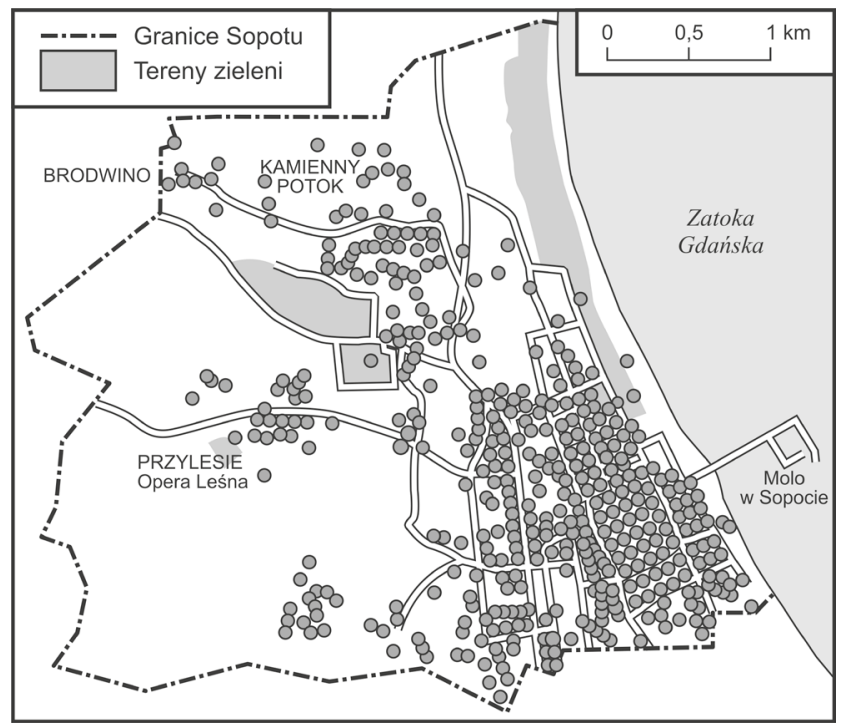

Rys. 5. Obiekty zarejestrowane na platformie Airbnb na terenie Sopotu

Źródło: opracowanie własne na podstawie AirDNA (15.11.2017) 


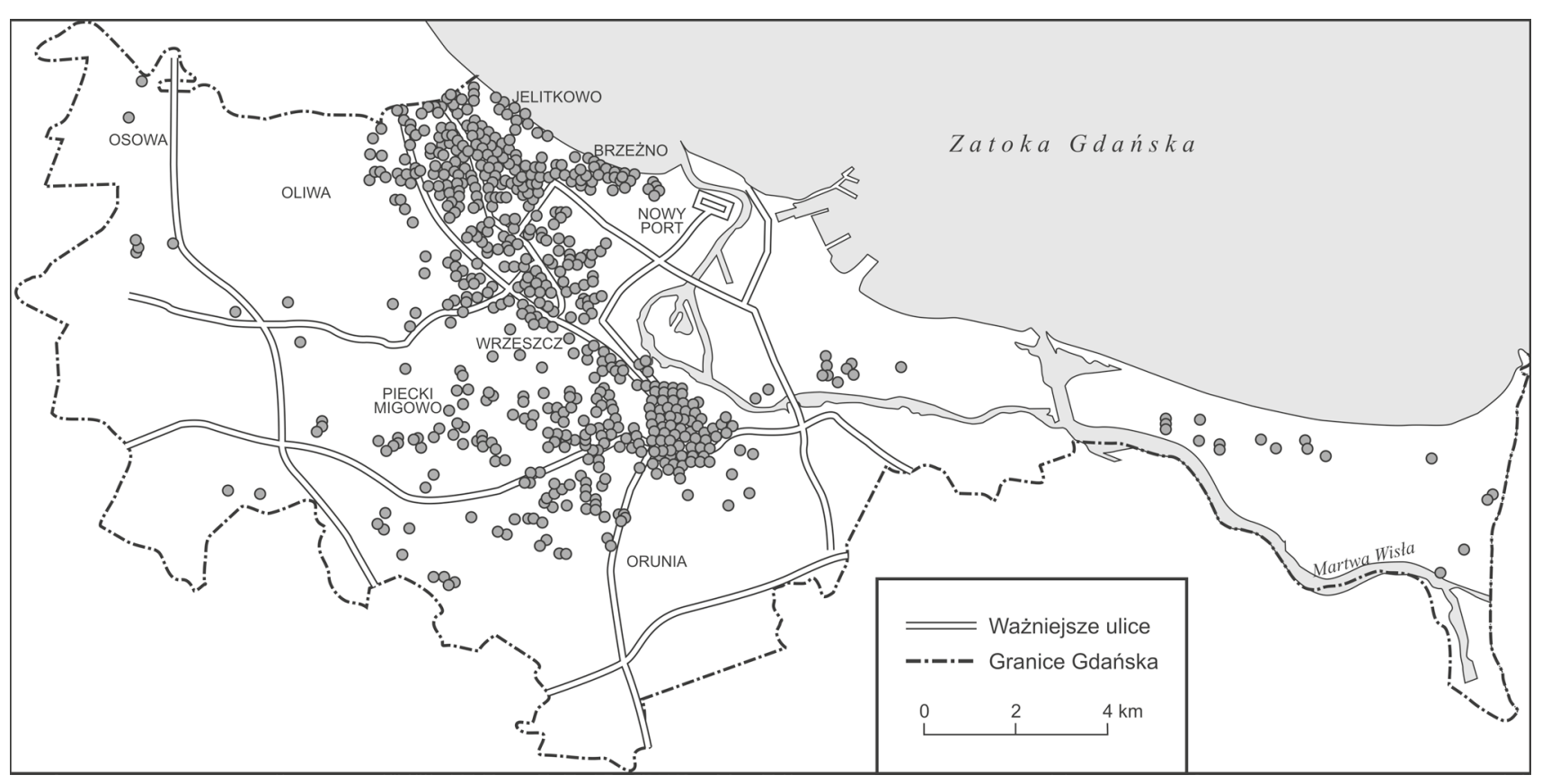

Rys. 6. Obiekty zarejestrowane na platformie Airbnb na obszarze Gdańska Źródło: opracowanie własne na podstawie AirDNA (15.11.2017)

\section{PODSUMOWANIE}

Platforma Airbnb prezentuje w ostatnich latach bardzo dużą dynamikę przyrostu oferty krótkoterminowego najmu lokali mieszkalnych w polskich miastach. Zjawisko to można postrzegać wielowymiarowo. $\mathrm{Z}$ jednej strony po części rozwiązuje problem typowy dla wielu polskich miast, tj. niedorozwoju infrastruktury noclegowej. Działania te nie tylko zwiększają potencjał recepcyjny miasta, ale także aktywizują lokalną społeczność w zakresie świadczenia usług turystycznych. W efekcie Airbnb może nie tylko generować dodatkowe źródła dochodów, ale także rodzić liczne korzyści natury społecznej, takie jak: otwartość na innych, tolerancję, poczucie bycia potrzebnym czy chociażby poprawę umiejętności posługiwania się językami obcymi. Z drugiej strony jest dostrzegalny już obecnie coraz wyraźniej negatywny wpływ najmu krótkoterminowego na sytuację w miastach. Po pierwsze uwidacznia się to w niekorzystnej strukturze gospodarzy obiektów, wśród których przeważają tzw. multigospodarze, udostępniający wiele ofert, co świadczy o zaawansowanej profesjonalizacji oferentów. Gyódi (2018) na przykładzie Warszawy stwierdził, że tylko niewielka część tej oferty może być określana z tego względu jako sharing economy. Po drugie najem krótkoterminowy staje się silną konkurencją dla tradycyjnej bazy noclegowej. Przewaga najmu krótkoterminowego wiąże się przede wszystkim z niższymi cenami oferowanymi na rynku, których przyczyn można doszukać się w niższych kosztach działalności, stosunkowo dużej skłonności do unikania przez gospodarzy Airbnb wszelkich opłat fiskalnych - nie tylko podatku dochodowego, ale także chociażby opłaty miejscowej czy opłaty za wywóz śmieci, co w efekcie finalnym obniża wpływy do kasy miasta i przenosi wiele opłat na barki stałych mieszkańców. Po trzecie wraz z dynamicznym wzrostem ruchu turystycznego silnie pobudzony popyt na najem krótkoterminowy generuje znacznie wyższą stopę zwrotu niż inne formy wykorzystania bazy mieszkaniowej w miastach. Następstwem tego może być przeznaczanie całych kwartałów w atrakcyjnych częściach miasta na cele najmu krótkoterminowego, co będzie wiązać się z pozbywaniem się z tej części miasta mieszkańców oraz tradycyjnych form działalności gospodarczej.

Wciąż otwarte pozostaje pytanie: czy sharing economy znacząco zmieni dynamikę rozwoju sektora turystycznego w najbliższych latach. Bezsprzecznie ten nowy model biznesowy, jak zauważa Sigala (2017), stwarza możliwości, ale też wyzwania dla podróżowania, gospodarki gościnności i destynacji turystycznych. Wydaje się, że najem krótkoterminowy w aspekcie turystycznym jest dość silnie powiązany z tzw. tanimi liniami lotniczymi. Wraz z zakładanym rozwojem siatki połączeń niskobudżetowych przewoźników w ośrodkach wielkomiejskich można spodziewać się rosnącego zapotrzebowania na ten typ oferty.

\section{PRZYPIS}

${ }^{1}$ Zarówno inicjatywa Inside Airbnb, jak i coraz większa grupa opracowań traktuje dostępność całoroczną lokalu jako jego 
udostępnienie na portalu Airbnb przez 10-12 miesięcy i 7-9 miesięcy. Takie rozumienie pojęcia "lokal całoroczny" przyjęto w tym artykule.

\section{BIBLIOGRAFIA}

Adamiak, Cz. (2018). Mapping Airbnb supply in European cities. Annals of Tourism Research, 71 (C), s. 67-71.

AirDNA. Pobrane z: https://www.airdna.co/ (15.11.2017).

Botsman, R. (2013). The sharing economy lacks a shared definition. Fast Company (21 Nov.).

Buhalis, D. (2003). eTourism: Information technology for strategic tourism management. London: Pearson (Financial Times/ Prentice Hall).

Czernek, K., Wójcik, D. (2017). Gospodarka współdzielenia z perspektywy przedsiębiorców sektora turystycznego. Handel Wewnętrzny. Tom I, 3 (368), s. 66-76.

Dredge, D., Gyimóthy, S. (2015). The collaborative economy and tourism: Critical perspectives, questionable claims and silenced voices. Tourism Recreation Research, 40 (3), s. 286-302.

Freytag, T., Bauder, M. (2018). Bottom-up touristification and urban transformations in Paris. Tourism Geographies, 20 (3), s. $443-460$.

Gutiérrez, J., García-Palomares, J.C., Romanillos, G., Salas-Olmedo, M.H. (2017). The eruption of Airbnb in tourist cities: Comparing spatial patterns of hotels and peer-to-peer accommodation in Barcelona. Tourism Management, 62, s. 278-291.

Guttentag, D. (2015). Airbnb: disruptive innovation and the rise of an informal tourism accommodation sector. Current Issues in Tourism, 18 (12), s. 1192-1217.

Gyódi, K. (2018). Airbnb and the hotel industry in Warsaw: An example of the sharing economy? Central European Economic Journal, 2 (49), s. 23-34.

Habibi, M.R., Kim, A., Laroche, M. (2016). From sharing to exchange: An extended framework of dual modes of collaborative non ownership consumption. Journal of the Association for Consumer Research, 1 (2), s. 277-294.

Hamari, J., Sjöklint, M., Ukkonen, A. (2016). The sharing economy: Why people participate in collaborative consumption. Journal of the Association for Information Science and Technology, 67 (9), s. 2047-2059.

Kowalczyk-Anioł, J. (2018). Koncepcja gentryfikacji turystycznej i jej współczesne rozumienie. Prace Geograficzne, 154, s. 35-54.

Kowalczyk-Anioł, J., Zmyślony, P. (2017). Turystyka miejska jako źródło protestów społecznych: przykłady Wenecji i Barcelony. Turystyka Kulturowa, 2, s. 7-36.

Lyons, K., Wearing, S. (2015). The sharing economy issues, impacts and regulatory responses in the context of the NSW Visitor Economy. Sydney: NSW Business Chamber.
Majchrzak, K. (2016). Ekonomia dzielenia się i jej przejawy w turystyce. Ekonomiczne Problemy Turystyki, 33, s. 21-30.

Mermet, A.C. (2017). Airbnb and tourism gentrification: Critical insights from the exploratory analysis of the 'Airbnb syndrome' in Reykjavik. W: M. Gravari-Barbas, S. Guinand (eds.), Tourism and gentrification in contemporary metropolises (s. 52-74). London: Routledge.

Paulauskaite, D., Powell, R., Coca-Stefaniak, J.A., Morrison, A.M. (2017). Living like a local: Authentic tourism experiences and the sharing economy. International Journal of Tourism Research, 19 (6), s. 619-628.

Pawlusiński, R. (2017). Ekonomia współdzielenia: istota zjawiska oraz wyzwania dla sektora turystyki w miastach. W: M. Drewnik, M. Mika (red.) Człowiek i jego działania. Spojrzenie geografa. Prace dedykowane Profesorowi Włodzimierzowi Kurkowi (s. 179-191). Kraków: Instytut Geografii i Gospodarki Przestrzennej Uniwersytetu Jagiellońskiego.

Pizam, A. (2014). Peer-to-peer travel: Blessing or blight? International Journal of Hospitality Management, 38, s. 118-119.

Sans, A.A., Quaglieri Domínguez, A.Q. (2016). Unravelling Airbnb: Urban perspectives from Barcelona. W: A.P. Russo, G. Richards (eds.), Reinventing the local in tourism: Producing, consuming and negotiating place (s. 209-228). Bristol: Channel View Publications.

Sigala, M. (2017). Collaborative commerce in tourism: implications for research and industry. Current Issues in Tourism, 20 (4), s. 346-355.

Sinclair, M. (2016). Fair and efficient regulation of the sharing economy. Economic Affairs, 36 (2), s. 204-211.

Skalska, T., Markiewicz, E., Pędzierski, M. (2016). Konsumpcja kolaboratywna w obszarze turystyki. Próba prezentacji zjawiska na rynku polskim, Folia Turistica, 41, s. 165-190.

Stors, N., Kagermeier, A. (2015). Motives for using Airbnb in metropolitan tourism - Why do people sleep in the bed of a stranger? Regions Magazine, 299 (1), s. 17-19.

Stors, N., Kagermeier, A. (2017). The sharing economy and its role in metropolitan tourism. Tourism and gentrification in contemporary metropolises: International perspectives. W: M. Gravari-Barbas, S. Guinand (red.), Tourism and gentrification in contemporary metropolies (s. 181-206). London: Routledge.

Wachsmuth, D., Weisler, A. (2018). Airbnb and the rent gap: Gentrification through the sharing economy. Environment and Planning A: Economy and Space, 50 (6), s. 1147-1170.

Wyrwińska, K., Wyrwiński, M. (2018). Platformy internetowe jako narzędzia ekonomii współdzielenia. Transformacje Prawa Prywatnego, 2, s. 91-112.

Artykuł wpłynął: 12 maja 2018

Zaakceptowano do druku: 18 grudnia 2018 